\title{
Law of the Director: Questioning the Unquestioned in Asghar Farhadi's Movies The Beautiful City, Fireworks Wednesday and The Salesman
}

Ma'soome Sehat, Hossein Jahantigh*

Faculty of Foreign Languages, Yazd University, Yazd-Iran

Corresponding Author: Hossein Jahantigh, E-mail: masomehsehat@gmail.com

\section{ARTICLE INFO}

Article history

Received: March 19, 2018

Accepted: June 27, 2018

Published: August 31, 2018

Volume: 9 Issue: 4

Advance access: July 2018

Conflicts of interest: None

Funding: None

Key words:

Barthes,

Farhadi,

Modernity,

Partiality,

Point of View,

Semiology,

Tradition

\begin{abstract}
Asghar Farhadi, the Iranian Oscar winning writer and director, employs a bitter reality, i.e. the clash between tradition and modernity, as the main motif of his works up to 2016. His depicted characters always attempt to act rational, a prerequisite of modern time, but something traditional almost by an accident pushes them back, and as a result, tradition comes out as the winner. The key concern in this paper is to examine how Farhadi, apparently, tries to portray the Iranian society by exercising an objective stance to raise his fundamental question. The paper analyzes how he presents the challenge to his audiences' judgment by letting them choose freely between modernism and tradition. However, the semiotic study of some of his movies shows his viewpoint is not completely objective and preference of one side over the other is apprehended. This paper seeks to prove that the author is inclined toward modernity in the titular three movies: The Beautiful City, Fireworks Wednesday and The Salesman, which the viewers might miss out on their first seeing of the movies.
\end{abstract}

\section{INTRODUCTION}

Iranians were exposed to Modernism in the middle of the $19^{\text {th }}$ century through such imperialists as Russia and Britain. Afterwards, the gap, and accordingly the conflict, between modernity and tradition grew deeper and deeper. This reality is reflected in different works of art from different perspectives. Some artists serve as a catalyst for transition to modernity, while many others refer to it as the illness of westernization. The eponymous director, Ashghar Farhadi, comes up with his own particular philosophy on the clash between modernity and tradition, that is, he wants to show this reality of society impartially. In the interview with Zeinab Kazemkhah from the leftist newspaper, E'temad (2016) he mentions his intention is to make his audiences observe their surrounding and question the problems.

In the three selected movies: The Beautiful City (2004), Fireworks Wednesday (2006) and The Salesman (2016), the clash between modernity and tradition is one of the main motifs. Farhadi artistically plays with a simple question: "who is right?" or "who is to blame?" and consequently he involves his audiences in the story by putting their judgment into question. His viewpoint seems objective in all his works as if he wants to show different sides of the clash and let his audience choose at will, although he wants them to believe that tradition is hard to escape. Tradition is the winner in all these movies as if the conventional society is the one which makes the decision, albeit, it does not mean Farhadi is satisfied with it. Despite the surface meaning, applying a semiotic study reveals that all these movies are inclined toward modernity.

Based on semiology, although sign as "ideology is often masked in naturalized framings of the common-sense," it refers to meanings beyond itself. Thus, the analyst's duty is to decode for the readers as to "whose view of reality is being privileged" (Page, 2014, p. 315). In this regard, different semiotic elements of these movies, including shots, camera and their perspective, frames, colors and dialogues are scrutinized.

Therefore, the first part of the paper is allocated to elaborate upon different signs of tradition and modernity and the dilemma in choosing one of them in the three movies in question. In the second part, it tries to reveal the preference for modernity.

Farhadi, his style of writing and filming, and his perspective toward life, have been the topic of many pieces of 
research. Tina Hassannia (2014) in Farhadi: Life and Cinema has provided a biographical collection of information, Majid Hosseini and Zaniar Ebrahim (2018), also, have observed Farhadi's cinema from a Lacanian point of view. Moreover, Kambiz Partazian (2013) finds the concept of modernity-tradition clash in Farhadi's Fireworks Wednesday interesting, also, Bahare Nadimi (2014) zooms in on the challenge of judgment in About Elly and The Separation, all in comparative studies. Nevertheless, no research has been conducted on these three movies with respect to their partiality toward modernity.

Modernity here does not refer to a significant movement but to a new style of life prone to give the past and whatever belonging to it, a second thought. Tradition spouses fixed conventions difficult to ignore or overpass while modernity offers the valor man needs to pass the boundaries. Although at first glance modernity seems privileging, its side effects such as alienation, death of individualism, reification and commodification are reasons enough to make us doubt its priority over tradition.

\section{METHODOLOGY}

Roland Barthes discussed signs carrying both denotation (literal meaning) and connotation (subjective meaning) in cinematic critique by extracting Ferdinand de' Saussure's concept of signifier and signified. In his book titled Elements of Semiology, Barthes (1983) declares: "The sign is a (twofaced) slice of sonority, visuality, etc. The signification can be conceived as a process; it is the act which binds the signifier and the signified, an act whose product is the sign" (p.48). He continues that the distinction is not based on phenomenological facts since a given sign's value comes from its surrounding and by analyzing the semantic process, it means the signs refer to something beyond the surface, which is not necessarily based on systematic or phenomenological facts and can simply be considered arbitrary. In a similar fashion, this paper, by decoding the different signs of these movies, will disclose the partiality for modernity.

Modernity is an epochal shift from traditional orders. It abdicates metaphysical beliefs by centralizing human being and his power of reason. Therefore, a new style of life and way of thinking is presented with its own consequences, among which, subjectivity, universality and relativism are the most fundamental ones.

Farzin Vahdat in God and Judgment (2002) reflects on two pillars of modernity from a Hegelian standpoint. The first pillar of modernity is "subjectivity," which refers to "characterizing the autonomous, self-willing, self-defining and self-conscious individual" (Vahdat, 2002, p.1). A man can freely choose his own way of life, putting aside all social standards. The second pillar is "universality," "the mutual recognition among the plurality of subjects of each other's subjectivity" (Vahdat, 2002, p.1). In other words, modernity glorifies individual rights regardless of their backgrounds.

Relativism, on the other hand, means "there are no defensible absolute notions of morally justified action or justified belief" (Baghramian, 2015, p. 3). Nothing is totally true and things can be judged, regardless of outside issues such as religion.

By scrutinizing these elements of modernity, this paper tries to highlight the modernity signs in the three selected movies to highlight the partiality of the director toward modernity.

\section{SINGS OF MODERNITY AND TRADITION}

Modern characters in Farhadi's movies respect the two pillars of modernity, against which the traditional society stands with all its written and unwritten standards. Respecting the first pillar called subjectivity, the representatives of modernity in his movies try to have their own say. They, also, respect others' rights more than normal by highlighting universality, the second pillar of modernity.

The Beautiful City is the story of an adolescent prisoner, named Akbar, awaiting execution, which is due the following week, just at his turning to age 18. A'la, his friend, is let out of penitentiary to negotiate with Abolghasem, the man whose daughter was murdered by Akbar. His agreement will alleviate Akbar's punishment. A'la believes Akbar deserves to be alive and nothing can stop him from changing Abolghasem's mind, signifying the two pillars of modernity referred to above. Abolghasem, however, has an inveterate tendency to take revenge. A'la is the representative of modernity, eager to change irrational conventions, shown in his life wish for Akbar and Abolghasem is the sign of tradition, overwhelmed by conventional life, shown in his death wish for Akbar. The conflict between these two characters is the reminder of the clash of ideas between the groups they are representing. "Which one is right?" A'la, who believes Akbar has murdered Malihe for the sake of love with her own consent or the man whose only daughter is killed. In this regard, "Farhadi handles this complex moral predicament with utmost compassion and sincerity. He allows the natural flow of events to account for his characters' rationale in negotiating with their own trials and tribulations" (Arsaib). Artistically, the audience is put in a dilemma which continues up to the end.

While the question of the movie seems unanswered, tradition is the winner. Although Abolghasem changes his mind, he remains conventional by replacing his dead daughter with his step-daughter while A'la needs to sacrifice his future to retrieve his friend's past. The dilemma is between universality and subjectivity: rescuing Akbar by ruining his future through marrying him off to a disabled girl or ignoring him and having his own choice of life.

Although deciding between these two is not an easy job, the clash is not as complicated as in Farhadi's later movies. After this movie, Farhadi becomes closer to his own "tier of society" (Hassannia, 2014, Interview), that is, the middle-class. Fireworks Wednesday is moving toward the middle-class Iranian society by depicting their problems. The title of this movie calls to mind the debates of tradition versus modernity. A traditional Persian celebration of jumping over the fire is turned to a completely different one with the arrival of fireworks and bonfires. 
This movie is the story of two women: Simin, a divorcee, who is in a secret relationship with Morteza in her neighborhood and Mojde, Morteza's wife, going nuts, by suspecting them. Simin is a modern woman who chooses her own way of life subjectively: she has gotten divorced and works to live off her own income while Mojde stays at home seeking her husband's love, not belonging to her anymore.

In the middle-class part of society of Fireworks Wednesday, the tradition versus modernity debate is far deeper, as it depicts people who want to act modern but remain obedient to conventions. The best example of this is Morteza, oscillating between these two extremes. On the one hand, the conventional society does not let him cut his marital life short easily, especially when a child is involved. On the other hand, he is in an illicit relationship with another woman. Not only is such a relationship modern in its nature but also the involved woman is the sign of modernity. In a similar vein, as in the previous movie, tradition is the winner here. Simin breaks up with Morteza, forcing him to go back to Mojde, while Roohangiz, a representative of tradition from another viewpoint, goes back to her husband happily.

The Salesman is the repetition of Farhadi's famous question but this time around a smaller scale and dealing with individual private issues. Emad of The Salesman wants to act like a modern avant-garde man. In the first thirty minutes of the movie, he looks like the one he himself wishes: a culture-wise person who does his best to enhance the society and people's attitude toward life. During the day, as a teacher, he encourages his students to read more and understand each other and in the evening, he acts in a theater to play the same responsibility for his society. Addressing Babak, his friend and partner in the theater, he says: "I wish I had a tractor, then I could destroy the entire city and reconstruct it anew" (Mallet-Guy, 2016, 0:15:15), which alludes to the fact that he wishes to reconstruct his society and people's mindset and beliefs.

One of the most crucial incidents in Farhadi's cinema happens at the $31^{\text {st }}$ minute of the movie, which serves as a catalyzer revealing the other side of Emad's personality, not only to the audience and other characters but to himself. Again, Farhadi's modern man behaves based on conventional rules of society and his avant-garde face gradually fades away and is replaced by a revenge-seeker. It seems his story turns out to be the replica of the story, The $\operatorname{Cow}^{1}$ (1969), by Gholamhossein Sa'aedi, that at the beginning of the movie he is analyzing for his students.

Student: How a person becomes a cow?

Emad: Gradually. (Mallet-Guy, 2016, 0:06:57)

This dialogue is a foreshadowing for Emad's later radical transformation, on which the whole movie is based.

In this movie, the familiar suspense of "who is right?" challenges the audience's judgment in the sequence of introducing the old man as the guilty part of R'ana's accident which never comes to an end. The man who has assaulted $\mathrm{R}$ 'ana is too weak, and the audience is fretting about his being punished by Emad and his desire to take revenge.

Moreover, as in the previous two movies, tradition can be assumed as the big winner in this movie, too. The moment that R'ana, as Linda of the Death of a Salesman, says farewell to Billy's dead body being played by her husband, Emad, is a farewell to the modern side to Emad's personality, which figuratively dies at this moment. Like the ideal man of his conventional society, he duly punishes the assaulter of his family and takes his revenge. This is never accepted from a member of the modern society, since based on the pillar of universality, nobody is allowed to judge others and violate their rights.

\section{PREFERENCE FOR MODERNITY}

Two-times Academy Award-winning director, Farhadi, owes a big part of his success to his movie scripts. No single action is meaningless in his works, each of which adds some meaning and can count as an answer to one of the thousand questions the audience might have. Owing to this, his audiences need to see the movie a second time.

In an interview with the Iranian newspaper, E'temad, Farhadi refers to this fact of his movie-making by distinguishing between symbol and sign (2016). He adds that in his works there is no symbol but signs. Small pieces of detail, which make the meaning of the whole movie, are put together, the same as an address consisting of small pieces of information guiding to one particular spot. It is similar to what the semiotic critic, Barthes (1983) refers to as two planes of the syntagma "a combination of signs, [in which] each term derives its value from its opposition to what precedes and what follows" (p. 48), and the associations: "the units which have something in common associated in memory and thus form groups within which various relationships can be found" (Barthes, 1983, p. 58). Semiology is the study of these signs, which this paper employs.

Farhadi's cinema constructs a society with fixed conventions from which, despite all their attempts, people cannot escape. In other words, tradition, as discussed in the previous part, is the master whose demands must be fulfilled.

By employing an objective viewpoint and open ending, Farhadi tries to provide an opportunity for the audience to choose between tradition and modernity freely. However, he is not always successful. His inclination to one side can threaten the audience's free choice. Therefore, the following discussion tries to show this inclination by elaborating upon different signs in the three selected movies.

The best example of this preference can be found in The Beautiful City. The opening credits of the movie is accompanied with sounds similar to army march and continues by Azan (Islamic call for prayer), and then the opening shot shows the national flag and a loudspeaker from which Azan is aired. It cuts to a mask being created by a young boy behind the bars. Having watched all these signs of tradition, the audience encounters an anarchic teenagers' party. Akbar, the boy who is supposed to be surprised with this birthday party, bursts into tears and leaves it. This is his eighteenth birthday, which for an adolescent murderer means end of life and execution punishment. The first quarter of the movie can be considered as a foreshadowing of the whole; some youngsters who try to enjoy their life while a traditional convention, death, ruins it. 
The representative of tradition in this movie is Abolghasem, the old man seeking Akbar's execution. Akbar killed his daughter two years ago and is now old enough to receive execution punishment. This notion of tradition seems so cruel that nobody advocates it. All characters in this movie from prison-guards to the old man's wife and even the Emam of mosque try their best to change Abolghasem's mind. Furthermore, religion, by the law of death penalty, puts a big obstacle in front of him. Based on Islamic jurisprudence, the financial compensation for a female deceased is half the male, therefore, the court will fulfill the execution as punishment only after Abolghasem's paying half of man's blood money to the murderer's heirs or family.

Everything is opposing Abolghasem's decision of taking revenge but he is insisting on it. Having been exposed to such an atmosphere, the audience finds it difficult to feel sympathy for Abolghasem and his conventional beliefs, instead, feelings are running high as the audience worries for Akbar, hence, tradition is condemned.

Moreover, the whole movie deals with the suspense of putting judgment into question, via which Farhadi asks his viewer to think twice about moral standards, leading to relativism. In this movie, Farhadi has created his characters in a way that all are right and wrong simultaneously. There is no black or white character while tradition is always the bad one.

Akbar was a 16-year-old boy when he killed Malihe just for the sake of love, the question is whether he is harmful to society, and, whether he deserves execution as punishment, while Abolghasem is sure about his right.

Emam: When a man is stuck in a dilemma, he should consult with somebody. Who is better than God for consulting?

Abolghasem: I am not facing a dilemma. (Taghipoor, 2004, 0:43:08)

Emam recites a verse of Quran to advise him to have mercy and forgive but Abolghasem insists on his right to take revenge. Emam goes on and says:

Emam: God wants you to forgive him.

Abolghasem: Then he is cruel too. (Taghipoor, 2004, $0: 44: 39)$

His wife goes through the same feeling when she wants to ask A'la to marry her disabled daughter, compensating Malihe's death. She feels guilty for ruining Ala's future. Her uncle makes her have no qualms about it by using this sentence: "Cruelty is the fact which gives you a disabled child and a dimwitted husband" (Taghipoor, 2004, 1:20:41). All these challenges are questioning the traditional life and its conventional standards.

Focusing on human right is one of the fundamental issues from a modernist perspective (Haghighi, 2001, p. 188). Akbar does not deserve death and A'la does his best to fulfill his right while enjoying the sympathy of the audience.

From the semantic viewpoint, the system of language and speech can be applied to system of objects and images including garment. The "systematized set of signs and rules" here replaces costume by the language and clothing by speech (Barthes, 1983, pp. 25-27). Fireworks Wednesday starts with portraying a happy couple. Their outfit and the motorcycle they are riding declare they belong to the lower classes of society. The girl's chador [veil] sticks to the motorcycle's wheel so they fall down. Chador is a sign of tradition, and its getting stuck in the wheel of the motorcycle, the sign of modernity, might put their marital life in danger. The movie ends with a shot with the same mise-en-scene, but this time around Roohangiz has got no chador. It is missed in the process of experiencing the modern life (Partazian, 2013, p. 168).

Roohangiz (refresher) as her name alludes, as a sign of tradition enters the modern life of Mojde to help her come out of mess. She brings both color to her house with uncovering the furniture, and hope to her life with a white lie about getting the tickets from Simin, which is so crucial to Morteza who has been suspected of having illicit affairs with the neighboring woman and whose book was about to be read by Mojde at this scene. However, these modern life's problems cannot be solved in such easy ways. At the end, Mojde remains doubtful and the one who has changed is Roohangiz herself. In the sequence of coming back to her husband, she insists on getting off the car sooner as if she is worried about her husband's tradition-bound judgment, what at the beginning of the movie in her relationship with bourgeois men such as her manager or Morteza cannot be found.

As Rouhi's reluctant involvement deepens, the light in her eyes dims. And her blissful expectations for the future are tainted by doubt. When Abdolreza [her husband] interrogates her at the end of an exhausting day, clouds have darkened the sunny skies. (Holden, 2011)

In the journey to the middle-class society, she becomes aware of problems marital life has in store for her in the near future. She comes to understand how hypocritical people can be and therefore how logical it would be if her husband suspects her coming back home without chador, late in the evening, and in a strange man's car. Her husband, however, is far from such problems of middle-class life. She is not wearing chador and it is late evening but he receives her with open arms saying: "What have you done? How pretty you've got?" (Saadatian, 2006, 1:36:00). The change in Roohangiz, her looks and her dress, is the result of being in contact with Simin, the representative of modernity. Morteza's wife is her foil character and sign of a middle-class traditional woman, the one staying at home waiting for her husband's love. All things about Simin are positive, in contrast to Mojde. She is portrayed in colorful clothes while Mojde is always in black. Besides, Mojde is called by all people, from neighbors to Morteza and even her own son, "crazy" (Saadatian, 2006, 1:01:57). In comparison to a bad-tempered woman like Mojde who enjoys the support of her family, neighbors and even Morteza, Simin has no protection in the society. Despite her kind-heartedness, all neighbors feel being in danger around her and because of their complaints, the owner of her apartment wants to take his flat back.

Putting all details together, the audience feels sympathy for her. Up to the $76^{\text {th }}$ minute of the movie, the audience cannot be sure about Mojde's suspicion, in spite of all signs and allegations referring to this fact. At this moment, Morteza and Simin are shown together in the car. She wants to break up her relationship while Morteza is weeping. Now the 
audience gets sure about what Mojde is always complaining about. However, their conversation does not permit the audience to change his mind about Simin. She is there to break up their relationship while Morteza is resisting:

Morteza: Are you in Tehran during Nowruz holiday?

Simin: Look, Morteza, we are not kids anymore. If your wife sees you with a prostitute, it would be much easier for her than now that you are in such a relationship.

Morteza: I'll call you.

Simin: See, I won't answer, it'll worsen our mood.

Morteza bursts to tears after hearing that and goes on:

Why don't you understand? I cannot stand it.

Simin: Indeed you can. My husband was in love with me [sobbing] but suddenly he disappeared.

Morteza: Stop talking like this.

Simin: Imagine it was just a dream.... Who the hell is Simin? (Saadatian, 2006, 1:19:57-1:22:00)

Who can blame Simin after such a conversation? Nevertheless, the empathic cycle toward her is not finished here. Right after leaving her lover for the sake of another woman's happiness, Simin freaks out since two boys annoy her by tossing a noisemaker explosive in her pass. Scared to death, she escapes to Mortaza's shelter but he is not there anymore. The audience's feeling which has been about to change, after watching these sequences remains sympathetic to Simin.

The last sequence of having Simin in frame is the one in which she is coming back home and her daughter is waiting for her eagerly. Not only is it too difficult for the audience to condemn a mother who has to live far from her child but also for a frank girl like Roohangiz:

Instantly, instinctively, she [Roohangiz] has entered the world of little secrets and lies that comes with the territory of marriage, and her open, beautiful face becomes clouded with fear and unease as she guesses what might be in store for her in the married future. (Bradshaw, 2014)

As a result of this, her frank behavior is covered by duplicity, which she has learnt from the middle-class lifestyle.

Ramin Jahanbagloo (2000), the famous Iranian Philosopher and academic, mentions "in Iran we do not have modernity, we are only wearing its mask; whenever it drops the calamitous visage of our philosophy and policies is revealed" (as cited in Partazian, 2013, p. 97). In The Salesman, having experienced a harsh accident, Emad cannot act rational like a modern man and takes revenge, as a condemned traditional action. Thus, he deserves to be criticized severely, the fact featuring consecutively in the movie in different ways.

Firstly, what happens to him and his wife was an accident. The previous tenant who used to live in their house was a prostitute. Mistakenly thinking it is the same prostitute; a man enters their house and does what seems to be an assaulting. Moreover, R'ana herself buzzes the door. It means the assaulter does not enter by force. For such an accident, seeking a culprit seems technically meaningless.

Secondly, the personae responsible for this accident can have a crucial role in Emad's condemnation. In his inquiries Emad is looking for a young man, shockingly, he comes across an old man, a well-loved father and husband,
"Everything to me, my whole life" (Mallet-Guy, 2016, $1: 52: 16)$ are the phrases his wife uses to describe him. Moreover, his daughter is about to marry and he, in spite of being retired, works hard to afford a suitable dowry.

The appearance of the elderly man is what makes Emad miss his little left chance of justification. He is a weak old man with a heart case. Much shorter than young Emad who calls the old man "dear father," the man has a round face covered with thick glasses which leaves the reader no choice but sympathy.

Thirdly, when the old man, the guilty part of Rana's accident, is arguing with Emad, not only is he shorter than Emad but he stands in a lower place too. Moreover, in almost all sequences, Emad is standing above the sitting or lying down old man, such a position in a struggle conveys the superiority and strength of the upper character over the lower one. Emad seems far stronger than the old man, consequently, the audience wants him to stop and let the old man go.

The mise-en-scene of Emad's caring his neighbor at the beginning repeats exactly at the end of the movie. The same stairs and position are chosen initially to remind us for the last time that Emad did not use to be an ordinary man but an avant-garde one. For sure, this sequence guarantees the following sequence's aim of condemning Emad. When the old man is about to die, Emad is watching him from the window of the second floor heartlessly. Being set in this high position leads to his definite condemnation.

On top of that, the director decides how long each sequence should be. Changing the allocated time to each sequence might change the significance of themes and accordingly the plot: "In Farhadi's world, a simple pause can speak volumes" (Croll, 2016). He knows where to stretch the evidence and where to cut it short.

The shot of Emad and R'ana in their empty apartment for the last time in which they are dealing with revenge rift is just a too long argument with no action. Farhadi allots nearly 30 minutes to what Ben Croll calls "dancing around" to give R' ana and Emad enough time to express their feeling, paving the way for the conclusion a traditional-seeker like Emad deserves.

Farhadi highlights this part significantly. There is a dilemma here for Emad: amending his hurt identity on the one side and making a rational decision, on the other side. His choice is definitely the former one. Farhadi's emphasis on this clash of ideas makes Emad's decision a costly mistake. He cannot overcome the problem which R'ana, the firsthand victim, surpasses easily.

The movie ends having Emad and R'ana in the frame. They are under make-up to get ready for acting as if they are putting masks society forces them to wear.

\section{CONCLUSION}

As discussed, the clash of modernity and tradition is one of the main motifs of Farhadi's three selected movies: The Beautiful City, Fireworks Wednesday and The Salesman. He believes in "the disastrous but near-invisible effect of modern time on the frazzled Iranian psyche, torn between tradition and modernity" (Hassannia, 2014, Introduction). This is 
exactly what different characters, in these three movies, are struggling with.

Putting audience's judgment into question, through digging up the past and usually in the middle of the anarchy of an accident, Farhadi implies an objective viewpoint, an assumption, which is not true. This paper, by studying semiotic elements of the three depicted movies, has elaborated on different signs of modernity and tradition in the first part focusing on challenging audience judgment and in the second part showing the partiality of the director for modernity in them.

Among scholars of our time, there are many who believe each society should use the capacity of modernity to redefine itself. One among these scholars is Alain Touraine (1990) who talks about contemporary modernity being divorced from its western source (Behnam, 2004, p. 12). It seems Farhadi enjoys a similar opinion.

\section{END NOTE}

1 This play has been turned into a movie bearing the same title by another eponymous Iranian director, Darius Mehrjui, in 1969.

\section{REFERENCES}

Arsaib, G. (2015,August 3). "Beautiful City (Iranian Film).” Retrieved from www.yam-mag.com/reviews/film-reviews/beautiful-city-2004

Baghramian, M. (2015). The Many Faces of Relativism. New York, NY: Routledge. DOI: $10.4324 / 9781315780153$

Barthes, R. (1983) Elements of Semiology. (A. Lavers and C. Smith, Trans.). New York, NY: Hill and Wan.

Behnam, J. (2004). The Future of Modernity in Iran. (A. Rahbar Shamskar, Trans.). In R. Jahanbagloo (Ed.), Iran: Between Tradition and Modernity (pp. 3-14). Lnham, MD: Lexington Books. DOI: 10.5860/choice.42-2978

Bradshaw, P. (2014, Feb. 6) "The Fireworks Wednesday Review." Retrieved from www.theguardian.com/ film/2014/feb/06/fireworks-wednesday-review

Croll, B. (2016 May 21). "The new Farhadi is good, not great." Retrieved from www.thewrap.com/the-sales- man-cannes-review-the-new-farhadi-is-good-notgreat

Farhadi, A.) 2016, Sept. 14). Personal interview with Z. Kazemkhah. Etemad newspaper, No.3625. cinemacinema.ir/conversation/\%D8\%A7\%D8\%B5\%D8\%BA\% D8\%B1-\%D9\%81\%D8\%B1\%D9\%87\%D8\%A7\%D 8\%AF\%DB\%8C-\%D8\%AA\%D9\%85-\%D9\%85\%D 8\%B4\%D8\%AA\%D8\%B1\%DA\%A9-\%D9\%81\%DB \%8C\%D9\%84\%D9\%85-\%D9\%87\%D8\%A7\%DB\% 8C\%D9\%85-\%D9\%82\%D8\%B6\%D8\%A7\%D9\%88\% D $8 \%$ AA/

Haghighi, Shahrokh. (2001). Beyond Modernity? Nietzsche, Foucault, Lyotard, Derrida. Tehran: Agah.

Hassannia, T. (2014). Asghar Farhadi: Life and Cinema. Raleigh, NC: Critical press. ISBN:

Holden, S. (2011, March 15). "Fireworks Wednesday," A Domestic Drama from Iran." Retrieved from mobile. nytimes.com/2016/03/16/movies/review-fireworkswednesday-a-domestic-drama-from-iran.html

Mallet-Guy, A. (Producer). Farhadi, A. (Director). (2016). The Salesman [Motion Picture]. France: Momento Films.

Saadatian, J. (Producer). Farhadi, A. (Director). (2006). Fireworks Wednesday [Motion Picture]. Iran: Boshra Films. Taghipoor, I. (Producer). Farhadi, A. (Director). (2004). The Beautiful City [Motion Picture] Iran: Neshane Films.

Page, J. T. (2014). Image with Messages: A Semiotic Approach to Identifying and Decoding Strategic Visual Communication. In D. Holtzhausen and A. Zerfass (Eds.), The Routledge Handbook of Strategic Communication. New York, NY: Routledge. DOI: 10.4324/9780203094440

Partazian, K. (2013). Taamol va taghabol sonat va modernite dar zendegie irani ba tamakoz bar sinemaye irani [Approval and Disapproval of Tradition and Modernity in Iranian's Life Focusing on Iranian Cinema]. Qom: A'alaaee.

Vahdat, F. (2002). God and Judgment. Syracuse University Press., DOI: 10.1017/s1356186302320157 